This item was submitted to Loughborough's Research Repository by the author.

Items in Figshare are protected by copyright, with all rights reserved, unless otherwise indicated.

\title{
The role of human mobility in promoting Chinese outward FDI: a neglected
} factor?

PLEASE CITE THE PUBLISHED VERSION

http://dx.doi.org/10.1016/j.ibusrev.2012.06.001

PUBLISHER

(C) Elsevier

VERSION

AM (Accepted Manuscript)

LICENCE

CC BY-NC-ND 4.0

\section{REPOSITORY RECORD}

Gao, Lan, Xiaohui Liu, and Huan Zou. 2019. "The Role of Human Mobility in Promoting Chinese Outward FDI: A Neglected Factor?”. figshare. https://hdl.handle.net/2134/14678. 
This item was submitted to Loughborough's Institutional Repository (https://dspace.lboro.ac.uk/) by the author and is made available under the following Creative Commons Licence conditions.

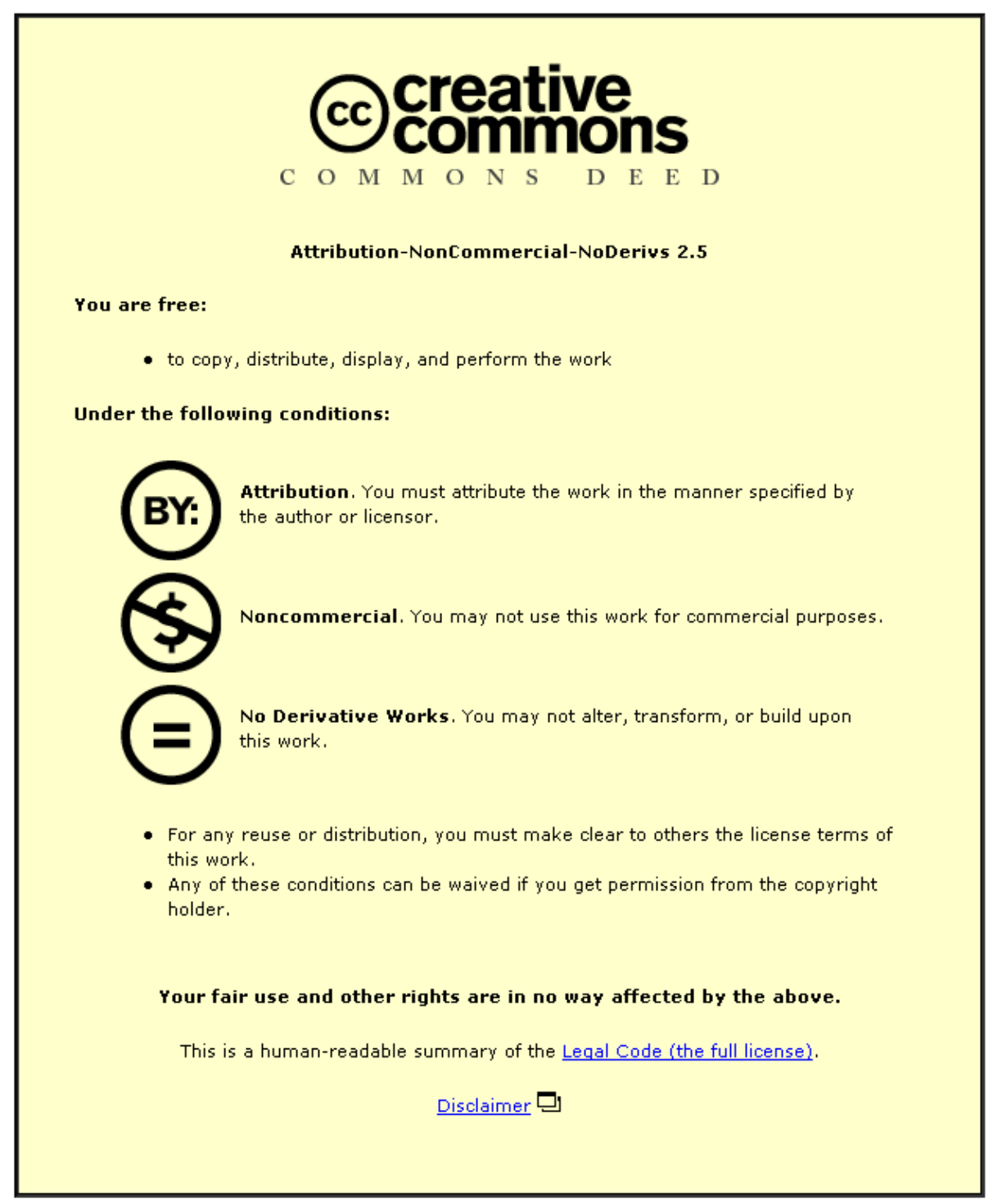

For the full text of this licence, please go to: http://creativecommons.org/licenses/by-nc-nd/2.5/ 


\title{
The Role of Human Mobility in Promoting Chinese
}

\section{Outward FDI: A neglected factor?}

\begin{abstract}
Extending Dunning's investment development path, this study examines the impact of human mobility, a neglected factor, on Chinese outward FDI using timeseries analysis. Our findings show that the two-way mobility of highly skilled Chinese students and scholars significantly promotes Chinese outward FDI. In addition, Chinese outward FDI is also driven by domestic economic development, but substitutes exports. The findings have important policy and managerial implications.
\end{abstract}

Keywords: Human mobility; investment development path; outward FDI; China 


\section{The Role of Human Mobility in Promoting Chinese}

\section{Outward FDI: A neglected factor?}

\section{Introduction}

Large scale outward foreign direct investment (OFDI) by firms in emerging economies has become increasingly prevalent in recent years. Rapid home economic growth, high commodity prices and FDI liberalisation in host countries have facilitated OFDI from emerging economies (The World Investment Report (WIR), 2010). In 2009, OFDI from emerging and developing economies reached a quarter of total global outflows (WIR, 2010). As one of the largest recipients of inward FDI (IFDI), China has emerged as an active player in global investment. In the year 2010, Chinese firms from non-financial sectors engaged in OFDI in 129 countries, establishing 3,125 overseas enterprises in both developed and other emerging countries (Ministry of Commerce, 2011). Alongside this wave of overseas investment, an increasing research effort has been devoted to examining issues related to OFDI from China.

Previous studies on the determinants of OFDI at country level have applied the investment development path (IDP) framework (Dunning, 1981; 1986; Dunning and Narula, 1996) to examine whether OFDI is driven by economic development, trade and IFDI (Liu et al., 2005; Zhang and Bulcke, 1996). The findings from these studies have shed light on the issues related to OFDI and enhanced our understanding of the relationship between OFDI and macro-level factors. However, the significant rise of human mobility has been largely overlooked in existing studies on OFDI. 
While traditional international trade theorists assumed that labour is immobile across national borders, the picture has changed dramatically in today's globalised world economy. The significant increase in migration has become a major aspect of globalisation (Docquier and Rapoport, 2011), and it is widely recognised that 'migrants make a valuable economic, political, social and cultural contribution to the societies they have left behind' (The Global Commission on International Migration (GCIM) report, 2005, p.23). However, the literature has barely identified the complexity of recent human mobility as it is 'not only becoming larger in scope and scale, but is also becoming more complex in its nature’ (GCIM report, 2005, p.7).

Further, there is limited discussion on human mobility in the context of emerging economies although migrants from emerging economies have become an important source of global human mobility, especially highly skilled migration. Six of the top ten original countries for international students are emerging economies, with China and India claiming the top two spots in 2009 (UNESCO, 2010). There is little empirical evidence to show whether the traditional 'brain drain' concern, caused by the emigration of highly skilled labour, may be converted into a network advantage (i.e. 'brain circulation') through two-way human mobility between developed countries and emerging economies (Saxianne, 2006; Tung, 2008).

People pursuing educational opportunities abroad represent an important trend, with implications for future highly skilled migration flows (International Organization for Migration, 2010). In 2009, the international mobile student flow reached a record level (2.8 million) with Chinese students alone accounting for around 17\% (UNESCO, 2010). According to the Ministry of Education of China (2011), by the end of 2009, among the 1.6 million Chinese international students, 
$30.7 \%$ had returned to China with their degrees, 50.8\% stayed abroad in full-time higher education, conducting doctoral or post-doctoral research, or working as visiting scholars, and $18.5 \%$ were working in industries overseas. Hence, China represents an interesting setting for examining the relationship between OFDI and human mobility.

Despite the significant increase in human mobility, very few studies have focused on whether this rise contributes to OFDI at the aggregate level. This represents an important research gap. This paper, therefore, takes a first step towards examining the impact of human mobility on Chinese OFDI. Building on the IDP framework (Dunning, 1981; 1986; Dunning and Narula, 1996), we suggest that human mobility should be considered a critical factor affecting the outward investment activities of local firms from emerging economies. More specifically, we investigate the impact of highly-skilled migrants who have pursued further education and work experience abroad. Complementing previous research on either diaspora (e.g. Smart and Hsu, 2004; Tung and Chung, 2010) or returnees (e.g. Filatotchev et al., 2011), we examine the two-way mobility by considering both those who still remain in foreign countries and those who have returned to their home country.

Our study makes three main contributions to the existing literature. First, it extends previous research on the impact of the Chinese diaspora by considering the two-way mobility of highly-skilled and well-educated human resources. By examining the role of human mobility in OFDI, we capture the impact of rapid globalisation through the lens of human mobility. Second, this study further provides new insights into the determinants of OFDI from emerging economies. In response to a recent call for understanding OFDI from emerging economies (Luo et al., 2010; Mathews, 2006; Morck et al., 2008), this paper adds empirical evidence by exploring 
whether OFDI from emerging economies, such as China, follows the universally standard pattern proposed by Dunning's IDP hypothesis, or whether new considerations are required to explain this phenomenon. We extend the IDP framework by taking into account the impact of the accelerated pace of human mobility. Finally, by highlighting the role of human mobility in Chinese OFDI, this study provides practical implications for policy-makers and practitioners. While the key government policy of facilitating OFDI aims to create an attractive environment to encourage domestic firms to invest abroad, mainly by providing financial support and other incentives (Luo et al., 2010), the findings from our study would contribute to a more 'soft-oriented' policy which emphasises the role of human mobility in facilitating OFDI.

This paper is organised as follows: Section 2 discusses the theoretical background and hypotheses. Section 3 describes the methodology and data, while Section 4 presents the empirical results. Section 5 discusses the findings and their implications, followed by the conclusion in Section 6 .

\section{Theoretical background and hypotheses}

\section{The IDP framework}

Drawing upon trade and investment theory, Dunning $(1977,1993)$ in his eclectic paradigm, proposed that firms are likely to pursue market-seeking, efficiencyseeking or resource-seeking FDI when expanding into international markets. The eclectic paradigm synthesised the main elements of various explanations for FDI and suggested that three conditions, notably ownership, location and internalisation advantages, are necessary for the existence of FDI. Ownership advantage is derived 
from firm-specific assets, such as technological and marketing knowledge, as well as superior managerial capabilities, whereas location advantage is related to the characteristics of a host country where MNEs may gain access to low-cost inputs and institutional support. Internalisation advantage rises when a firm exploits its ownership advantage within the boundaries of the firm by setting up subsidiaries across national borders instead of using market transaction (Dunning, 1977). Further, Dunning and his colleague (Dunning, 1981, 1986; Dunning and Narula, 1996) extended the eclectic paradigm and modelled the pattern of a country's FDI by linking the level of economic development with the FDI position.

The key argument in Dunning's IDP framework is that the level of a country's OFDI is closely linked with different stages of economic development. Dunning's IDP framework suggests that countries tend to go through five main stages of FDI activities. During the first stage of the IDP, counties attract very little IFDI because of weak location advantages, and undertake very little OFDI due to the lack of ownership and internalisation advantages. Foreign firms will prefer to export to and import from this kind of market. At stage 2, IFDI starts to rise, while OFDI remains low or negligible. A country at this stage is normally characterised by rapid economic growth and an enlarged domestic market, which attract a large amount of IFDI. Meanwhile, although elements of OFDI begin to emerge as firms have increased the ownership advantages compared to the previous stage, the value of OFDI is still small. Countries in Stage 3 are marked by a gradual decrease in the rate of growth of IFDI, and an increase in the rate of growth of OFDI. Domestic firms further develop their ownership advantages, and start to invest abroad. However, such countries are still net recipients of FDI. Stage 4 is reached when a country is a net outward investor, 
with OFDI equalling or exceeding IFDI, and OFDI growing faster than IFDI. At this stage, domestic firms can not only effectively compete with foreign-owned firms at home, but penetrate foreign markets. Beyond stage 4, both inward and outward FDI continue to increase. The net outward investment position of a country fluctuates near the zero level again, as in stage one.

A number of empirical studies have tested the validity of the framework and found a relatively strong causal relationship between OFDI activities and economic development (Barry et al., 2003; Bellak, 2001; Boudier-Bensebaa, 2004; Buckley and Castro, 1998; Dunning and Narula, 1996). However, Boudier-Bensebaa (2004) stressed that the level of economic development alone proxied by GDP per capita is inadequate to explain OFDI. It is in accordance with recent research in this field that other complementary variables are required to enhance the explanatory power in examining OFDI activities, including trade, IFDI and government policy (Buckley and Castro, 1998; Dunning and Narula, 1996; Liu et al., 2005; Zhang and Bulcke, 1996). While the findings from existing studies have broadened our understanding of a range of factors affecting OFDI (Liu et al., 2005), there are still key explanatory factors missing in these empirical studies. To respond to Dunning and Narula's (1996) call for detailed individual country studies in order to provide a better understanding of the determinants of a country's OFDI, this paper extends existing studies by incorporating the role of human mobility in OFDI activity into the IDP framework.

\section{Human Mobility, Network Theory and OFDI}

Prior research on human mobility has largely focused on the role of diaspora (Ng and Tuan, 2002; Smart and Hsu, 2004; Tung and Chung, 2010). One of the 
characteristic features of the diaspora is that they possess relational assets which are embedded in ethnic or familial networks within a specific minority population in host countries (Dunning, 2002; Erdener and Shapiro, 2005). The benefits of possessing relational assets can be explained by network theory which places great emphasis on human relations and highlights the fact that network-related factors may enable firms to access valuable information and resources (Batjargal, 2007; Coviello, 2006; Madhavan and Iriyama, 2009; Sharma and Blomstermo, 2003; Zhou et al., 2007).

Recent studies in the context of China have found that the Chinese diaspora contributed to a large proportion of Chinese IFDI from South and Southeast Asia and facilitated bilateral trade between these countries and China, especially in the early stages of China’s economic reform (Ng and Tuan, 2002; Smart and Hsu, 2004; Tung and Chung, 2010) and thereby started to facilitate Chinese OFDI (Buckley et al., 2007). Some studies have found that overseas Chinese investors have tended to rely heavily on ethnic and familial links in order to minimise risks and reduce psychic distance (Lau, 2003; Zhan, 1995).

However, previous research concerning the Chinese diaspora is rather static and narrow in its scope, as it mainly focuses on ethnic Chinese who reside in Hong Kong, Taiwan, Macau, South or Southeast Asia (Cheung, 2004; Smart and Hsu, 2004) and ignores the two-way human mobility between China and adopted countries, especially developed countries. In this era of globalisation, human mobility across national borders has become much more vibrant, with more migrants or specialists from emerging economies going abroad for education and working for MNEs, with some of them returning to China (Filatotchev et al., 2011; Wang, 2007). Networks established through such mobilisation are much broader than those formed by 
diaspora (Adler and Kwon, 2002; Kugler and Rapoport, 2005). This increasing scale of two-way human mobility in recent decades may significantly expand the business networks which Chinese firms can access and exploit.

In addition to the scale of human mobility, a distinct characteristic of the twoway human mobility is the increasing quality of migrants, as the majority consist of people pursuing higher education opportunities (Zhang and Li, 2002). The existing research indicates that the increasing quality of migrants is more likely to facilitate knowledge and information flow (Docquier and Marfouk, 2004; Filatotchev, et al., 2011). Such knowledge and information flow enables the development of networks which provide necessary platforms for the internationalisation of Chinese firms. Both permanent and temporary migrants with western education, appropriate language skills and international business experience are highly sought after by Chinese firms. They can help compensate for information asymmetry when entering unfamiliar business environments, and for the shortage of qualified staff with appropriate language skills and international business management experience (Child, 2001). Due to the shared cultural background, the communication between migrants and Chinese firms may be subject to fewer cultural barriers (Holbum and Zelner, 2010; Kaplan, 2008). The extensive network developed through two-way human mobility and the intensive knowledge embedded within this network may facilitate Chinese OFDI and help Chinese firms reduce the risks and uncertainty associated with overseas operations (Wang, 2007). Based on the above discussion, we incorporate network theory with a particular focus on two-way human mobility into the IDP framework and derive a number of testable hypotheses below. 


\section{Economic Development}

A country's level of economic development is the sole explanatory factor for the country's FDI position in the original IDP framework (Dunning, 1981, 1986; Dunning and Narula, 1996). Dunning (1981, 1986) argued that the ownership advantages accumulated during a country's economic development contribute to the country's FDI activities. As the economy grows, a country's location advantages gradually develop into ownership advantages, and domestic firms develop their own capabilities and accumulate operational experience which can be applied to their internationalisation process. The accumulated ownership advantages represent competitive advantages which can be exploited overseas. Therefore, the higher the level of its economic development, the more OFDI activities the country can generate. We maintain this core hypothesis postulated by the IDP framework and test whether the relationship between OFDI and economic development is still relevant. In other words, we seek empirical evidence on whether the level of economic development is still the foundation for Chinese OFDI. Hence, we hypothesise:

H1: Chinese OFDI is positively associated with the country's economic development.

\section{Human Mobility}

Human mobility externalities are an important channel through which migrants influence cross-border economic activities (Docquier and Lodigiani, 2010). Recent studies have shown that human mobility has become a distinctive feature in international knowledge diffusion between OECD countries and emerging economies such as China (Filatotchev et al., 2011; Jean et al., 2011). Such human mobility tends 
to contribute substantially to the flow of information and knowledge between China and host countries, which in turn may facilitate overseas investment by Chinese firms.

Networks are by nature dynamic as the development of networks evolves over time (Gulati et al., 2000; Hanaki et al., 2007). Hence, the impact of networks established through human mobility varies, depending on the scope and scale of human mobility. While earlier research has focused on the role of diaspora on IFDI in China, these studies can hardly capture the dynamic characteristics and the global scale of Chinese overseas networks (Ng and Tuan, 2002; Smart and Hsu, 2004; Tung and Chung, 2010). More and more Chinese students/scientists have studied/worked in developed countries, such as the US, Canada, Australia, the EU and Japan (Guo et al., 2009; Wang, 2007). From the broader perspective of human mobility proposed in this study, it is highly likely that such an accelerated pace of human mobility helps to expand the global network, which can be accessed by Chinese firms (Filatotchev et al., 2011; Kugler and Rapoport, 2005).

In addition, one major component of the human mobility phenomenon, Chinese international students, represents a distinctive body of knowledge and network-based resources, and is equipped with world-class skills and global connections to leading-edge technologies and overseas markets, all of which can be beneficial for their country's development (Saxenian, 2002). Saxenian (2006) further described return migrants in China and India as 'new Argonauts' and suggested that these 'new Argonauts' may act as a bridge between China and the outside world, and help to accelerate Chinese OFDI due to their global networks, multi-cultural experience and communication skills. Thus, we propose that: 
H2: Chinese OFDI is positively associated with the country's human mobility.

\section{Inward FDI}

IFDI, like OFDI, is determined by a country's economic development in the IDP framework and is often attracted by the host country's location advantages. It contributes to the host country's development through capital investment and productivity spillovers (Blalock and Simon, 2009; Chuang and Lin, 1999; Wei et al., 2008). More specifically, IFDI allows indigenous Chinese firms to accumulate their ownership advantages by learning from their foreign rivals in terms of new technology, organisational strategies and functional competence (Scott-Kennel and Enderwick, 2005). These newly developed ownership advantages can be further exploited in overseas markets (Dunning et al., 2001). In addition to productivity spillovers, IFDI is also seen to lead to better innovation performance by indigenous firms through technological spillovers (Li, 2011). All these positive effects of IFDI may encourage OFDI activities which exploit the ownership advantages accumulated through learning from their foreign rivals.

However, Backer and Sleuwaegen (2003) addressed a possible scenario in which IFDI could discourage entry and cause the demise of Chinese domestic firms in the short-run, suggesting that inexperienced firms may be squeezed out of the domestic market where competition becomes severe. In China, indigenous firms have long been at a disadvantage because the government has focused on attracting IFDI since the 1980s by allowing foreign firms to enjoy benefits, such as the removal of investment barriers, tax benefits etc. Therefore, indigenous firms were forced to compete with mature MNEs, despite insufficient financial capital, technology, 
management skills and experience. As indigenous firms grew fast and deregulation gave foreign MNEs more freedom, market competition intensified. Chinese firms therefore started to explore overseas markets by conducting defensive OFDI in order to further develop and exploit their ownership advantages abroad (Buckley et al., 2007), and escape from domestic institutional and market constraints (Luo and Tung, 2007; Witt and Lewin, 2007). Therefore, we propose that:

H3: Chinese OFDI is positively associated with the level of IFDI attracted to the country.

\section{Exports}

Dunning et al. (2001) found that there was increasing interaction between exports and the FDI position of a country as development proceeded. However, the impact of exports on OFDI is not clear cut. The debate about whether there is a complementary relationship or a substitution one between OFDI and exports has been undertaken for decades (Blonigen, 2005). The complementary relationship between exports and OFDI can be explained by the different advantages associated with OFDI versus exports. The lower marginal costs of OFDI contrast with the lower fixed costs and lower risks associated with exports. This leads to the complementary solution where MNEs serve a foreign market by both OFDI and exports (e.g. Head and Ries, 2001; Rob and Vettas, 2003; Swenson, 2004). On the other hand, since OFDI allows lower marginal costs of transportation, it may be a substitute for exports when there is enough demand in the foreign market to generate a high profit and cover the higher fixed costs associated with OFDI (Blonigen, 2005). Hence, the relationship between OFDI and exports depends on the trade-off between geographical proximity and 
production concentration. While firms may have incentives to reduce transportation costs by conducting OFDI in host countries, they could alternatively choose to concentrate production at home and then export to foreign countries. However, OFDI can help to overcome trade barriers and trade quotas in order to minimise possible international anti-dumping lawsuits.

In the case of China, fast economic growth has been largely driven by export demand. The government has been explicitly encouraging OFDI projects which can facilitate exports in order to maintain export growth. OFDI may complement exports so that Chinese firms may benefit from the advantages of both approaches to internationalisation. Chinese firms can still capitalise on the relatively low labour costs and vast production capability at home by exporting intermediate or finished products. Meanwhile, OFDI will enable Chinese firms to internalise the external markets, reduce transaction costs and overcome trade barriers. Thus, we hypothesise that:

H4: Chinese OFDI is positively associated with the country's exports.

\section{Knowledge Development}

Economic development proxied by GDP per capita in the original IDP framework does not take account of the structural changes involved in shifting from a labour-intensive economy to a knowledge-intensive one (Boudier-Bensebaa, 2004). Therefore, the level of knowledge development should be incorporated into the IDP framework in order to capture the increasing importance of the knowledge-based advantage in emerging economies, such as China. 
Existing research suggests a link between knowledge creation and the path of internationalisation because OFDI activities provide a means to exploit and explore knowledge-based assets (Lu et al., 2011; Meyer et al., 2009; Peng, 2001). In particular, some studies suggest that OFDI provides an additional opportunity to create new expertise or revitalise existing knowledge in new situations (Makino et al., 2002; March, 1991; Luo and Tung, 2007). A positive link between Chinese OFDI and domestically-acquired knowledge and experience is likely to be established, given that knowledge assets developed at home enable firms to better understand foreign market needs and to satisfy such needs through customisation in foreign countries ( $\mathrm{Lu}$ et al. 2011). It is evident that transferring and leveraging existing knowledge stock becomes a source of competitive advantage (Makino et al., 2002), and the global success of firm internationalisation is highly dependent on their home base where knowledge and experience are developed in order to serve international expansion (Luo and Tung, 2007).

In addition, it is well documented that knowledge development can enhance the overall competitiveness of a country (Porter, 1990). In other words, increased ownership advantages through continuous knowledge development help to establish competitive advantage. In particular, knowledge creation through research and development $(\mathrm{R} \& \mathrm{D})$ is considered a driving force for building national innovation capacity (Furman et al., 2002) which can help to boost overseas investment (Drake and Caves, 1992). Thus,

H5: Chinese OFDI is positively associated with the country's knowledge development. 
Therefore, combining the traditional IDP hypothesis (H1) with the four supplementary hypotheses, OFDI is considered to be a function of the following variables:

\section{OFDI $=f(H M$, GDPP, IFDI, EXPORT, KNOW $)$}

where HM stands for human mobility, GDPP is GDP per capita, IFDI denotes inward FDI to China, EXPORT denotes exports of goods and services, and KNOW represents knowledge development.

\section{Methodology and Data}

\section{Analytical Technique}

Following previous studies (e.g. Barry et al., 2003; Liu et al., 2005), this study adopts an aggregative approach using macro-level time-series data. The standard procedure for time-series analysis, including the unit root test, the cointegration test and the endogeneity test, is applied to detect certain characteristics of economic data which may influence the validity and reliability of regressions. These pre-tests are prerequisites for choosing an appropriate estimation method.

First, we test whether the variables have unit roots. If the time series are nonstationary or contain a unit root, we then need to perform cointegation tests to examine whether the variables are cointegrated and have a long-run equilibrium relationship. The variables are said to be cointegrated when they share a common trend in the long run because of underlying causal mechanisms (Zwinkels and Beugelsdijk, 2010). In other words, the cointegrated variables cannot deviate from each other for any extended period of time. The equilibrium error (the difference 
between the variables at a certain time) always fluctuates around the mean. This process of reverting to the mean is often referred to in econometric literature as errorcorrecting behaviour (Nair and Filer, 2003). Toda and Phillips (1993) show that levels of autoregressions are an unreliable basis for regression inference in the nonstationary case, since the coefficient and significance level of individual variables will be affected by the co-movement between the variables. This stable, long-run relationship among variables can be estimated by applying a vector error correction model (VECM), as the deviation of the equilibrium from its long-run relationship will be fed into its short-run relationship in the VECM (Burke and Hunter, 2005). The VECM can be written in the following form:

Error! Bookmark not defined. $\Delta Y_{t}=\alpha+\beta E C T_{t-1}-\sum_{i=1}^{n} \gamma_{i} \Delta X_{t-i}+\varepsilon_{t}$

1

where $\Delta$ denotes the differences, $Y_{t}$ is a dependent variable, $X_{t}$ is a set of explanatory variables and ECT is the residual term from a long-run equilibrium relationship between the variables (Burke and Hunter, 2005) and is defined as the error-correction term (ECT). A negative ECT indicates the converging behaviour of the variables which are cointegrated, whereas a positive ECT means that the variables diverge from the equilibrium and produce larger deviation, in which case the long-run prediction power of the model will be undermined (Maddala and Lahiri, 2009).

In addition, we test whether endogeneity between the dependent variable and independent variables exists. The independent variable is endogenous if there is a correlation between the variable and the error term (Burke and Hunter, 2005). In the 
presence of endogeneity, the coefficient in an ordinary least squares (OLS) regression is biased. Instead, the generalised method of moments (GMM) should be applied as it takes into account the reverse causation in the estimation.

\section{Data}

As discussed above, the augmented IDP framework is adopted to examine the determinants of OFDI at the macro-level. Thus, the aggregate time series data is appropriate for our empirical tests. Data for the tests proposed were obtained from various sources. OFDI and IFDI stock data were chosen rather than FDI flow data which is considered to provide a biased picture due to the lack of consistent series on re-invested earnings (Bellak, 2001). OFDI and IFDI stocks (in current US\$) were obtained from the UNCTAD database (2011). GDP per capita (in constant US\$ of year 2000), GDP deflator and exports (in constant US\$ of year 2000) were drawn from the World Bank indicator (2011). The data on human mobility were obtained from the China Statistical Yearbook (1980-2010). The variable of the stock of human mobility inflow (HMIS) is measured by the stock number of Chinese people who went abroad to study and then returned to China, and the variable of the stock of human mobility net flow (HMNS) is measured by the stock number of Chinese people who went abroad to study and remain in foreign countries. We use the inflow and netflow stock of Chinese international students and scholars to measure the international mobility of highly skilled Chinese people in order to capture its impact on Chinese OFDI (Chellaraj et al., 2005; Park, 2004). Investment in R\&D was drawn from various issues of the China Statistical Yearbook (1980-2010) as empirical findings illustrate that $\mathrm{R} \& \mathrm{D}$ investment alone can explain $89.2 \%$ of national innovative capacity (Furman et al., 2002). 
The value of OFDI stock, IFDI stock and investment in R\&D were deflated using GDP deflators $(2000=100)$. Constrained by the availability of the OFDI timeseries, the sample period is from 1979 to 2009. We also controlled for the impact of government policy on OFDI by including a dummy variable which takes the value of one from year 2001 when the Chinese government started the 'go global' policy which encouraged Chinese firms to invest abroad, and when China joined the World Trade Organisation (Lu et al., 2011).

\section{Empirical Results}

The augmented Dickey-Fuller (ADF) tests were first applied to test unit roots. The results from the ADF unit root tests are summarised in Table 1 and indicate that the null hypothesis (that there is a unit root in the level series) is not rejected for any of the six variables. However, all series are stationary in the first difference, so all the variables are integrated of order one. Therefore, regression models should be applied to the first differences of all the variables, which represent the growth rates of the variables.

\section{Put Table 1 here}

The results from the cointegration tests reported in Table 2 show that the variables are cointegrated, suggesting a long-term equilibrium relationship between the variables, which indicates that there are co-movements between OFDI, GDP per capita, human mobility, IFDI, exports, and investment in R\&D. The existence of cointegration suggests the use of VECM (Toda and Phillips, 1993); the lagged ECT, 
which represents the long-run equilibrium relationship among the variables, will be added into the estimation regressions in models 3-5. The results based on the VECM are presented in models 3-5 in Table 6.

\section{Put Table 2 here}

In order to select an appropriate estimation method for the determinants of Chinese OFDI, system exogeneity tests were performed to detect whether OFDI has a reverse effect on its explanatory variables. The results from the exogeneity tests, presented in Table 3, indicate that two-way causations exist between OFDI, HMIS and investment in R\&D. In this case, simple OLS regressions can only provide inadequate tests of hypotheses because of the reverse causation from OFDI to HMIS and investment in R\&D.

\section{Put Table 3 here}

Therefore, Equation 1 was estimated using the GMM in order to take account of endogeneity between OFDI and its explanatory variables. Table 4 presents standard deviations, means, and correlations of the variables, while Table 5 summarises the results from the variance inflation factor (VIF) test for models 3-5. The results from the VIF test indicate that the issue of multi-collinearity is not a concern as the VIFs of all the variables are far below 10, the acceptable cut-off point (Neter et al., 1996). 


\section{Put Table 5 here}

The GMM estimation results based on the VECM are reported in Table 6 alongside the OLS estimation of the original IDP framework (Model 1) and the variables tested by previous empirical studies (Model 2). Models 1 and 2 provide the baseline against which to compare the results of Models 3-5. The results show that the original IDP framework has very limited explanatory power, with an adjusted $\mathrm{R}^{2}=0.08$, in explaining Chinese OFDI. Although the explanatory power of the model is improved by adding IFDI, export and investment in R\&D in Model 2, an adjusted $\mathrm{R}^{2}$ of 0.46 indicates that there are still important explanatory variables missing. By adding human mobility variables, our results show a significant improvement in $\mathrm{R}^{2}$ to over 0.62 which indicates a substantial improvement in the explanatory power of the IDP model.

The coefficients of explanatory variables in Model 3-5 are largely consistent with the original IDP framework and previous empirical studies. A rise in GDP per capita is found to lead to an increase in OFDI, suggesting that the growth of GDP per capita is an important factor affecting Chinese OFDI growth. The variables of human mobility are strongly significant, showing a positive impact on Chinese OFDI. Therefore, hypotheses 1 and 2 are strongly supported. By contrast, export was found to be significant but with a sign contrary to that predicted in hypothesis $H 4$. The negative sign of export indicates that there is a substitute relationship between 
Chinese exports and OFDI. IFDI is only found to be significant in Model 3. Therefore, hypothesis $H 3$ is only partially supported. The result of the control variable shows a positive sign, but it is statistically insignificant. The ECT is negatively significant in Models 4 and 5, which partially implies that the variable does not move far from the equilibrium relationship in the long-run and that there appears to be a strong convergent tendency among the variables. This indicates that GDPP, HMIS, HMNS, IFDI, exports and investment in R\&D jointly affect the magnitude of Chinese OFDI in the long-run.

\section{Put Table 6 here}

\section{Discussion}

This study aims to examine the determinants of Chinese OFDI by analysing an under-explored factor, human mobility, and augmenting the IDP framework by incorporating the network theory. The new factor, human mobility, introduced in this study has been found to have a significant positive impact on Chinese OFDI. This finding shows that two-way human mobility in the era of globalisation may help to promote network building and knowledge flows across national boundaries, which in turn facilitate Chinese OFDI.

Previous research on the Chinese diaspora largely focused on their role in generating IFDI to China (Chen and Chen, 1998; Ng and Tuan, 2002; Smart and Hsu, 2004; Tung and Chung, 2010). In contrast, our study has examined the impact of two- 
way human mobility on Chinese OFDI. The concept of human mobility adopted here reflects the recent emerging trend of mobility of highly skilled labour across national borders. The distinctive characteristic of recent cross-border human mobility is that it consists of a highly skilled and well-educated labour force and two-way brain circulation. More than one million Chinese students/scientists have studied/worked or been studying abroad, and a quarter of these people returned to China (Ministry of Education, 2011), which indicates that China has experienced a substantial level of international human mobility. By capturing the impact of overseas networks formed by the frequent movement of human capital and the benefits of international migration, our finding suggests that such human mobility has played an important role in Chinese OFDI.

Using the stock data on Chinese international student inflow enables us to capture the impact of return migrants, who are described as 'new Argonauts' by Saxenian (2006). This group of returnees is embedded in the multi-cultural contexts of the country where they studied/worked and their home country, and is able to bring advanced technology and new ideas back to China and act as an important channel for knowledge and network transfer (Saxenian, 2006). Hence, human mobility represents a network advantage and a knowledge asset which can be exploited by Chinese firms in the process of internationalisation (Filatotchev et al., 2009; Gassmann and Keupp, 2007). Our findings at macro level also complement the literature on international entrepreneurship (e.g. Filatotchev et al., 2011; Jones et al., 2011; Spence and Crick, 2009; Zahra and Hayton, 2008) which has widely discussed the importance of the international experience of top management teams in pursuing global success. Human 
mobility, especially return migrants, provides an important base for the international experience of managers and entrepreneurs in emerging economies.

Our findings complement those based on either country level or firm level studies on outward FDI (Jean et al., 2011; Le, 2010; Park, 2004). For example, Kugler and Rapoport (2007) have found that FDI is positively associated with migration using aggregate data for the US. Research by Le (2010) and Park (2004) has shown that international students act as an important channel for R\&D spillovers between the host countries and their home countries. A study by Jean et al. (2011) at a firm level indicates that ethnic ties help to facilitate FDI location choice and firms tend to use ethnic ties to obtain knowledge and resources for internationalisation. Our study suggests that Chinese international students' engagement in world class universities, research institutions and MNEs may provide them with precious opportunities to acquire advanced knowledge, cutting-edge technology and international work experience which can be exploited by Chinese firms to enhance their own ownership advantages.

The significant positive relationship between Chinese OFDI and GDP per capita underpins the original IDP framework, which implies that Chinese OFDI is positively driven by its domestic economic development. The traditional IDP framework considers GDP per capita as an indicator of a country's economic development and reflects the country’s ownership advantage development (Dunning, 1981, 1986; Dunning and Narula, 1996). Our result provides further support to the traditional IDP hypothesis, and indicates that as ownership advantages accumulate through domestic economic development, Chinese firms start to exploit those advantages overseas. 
However, the insignificant relationship between Chinese OFDI and the country's knowledge development indicates that the ownership advantages of Chinese firms are based more on financial capacity than knowledge assets. It shows that Chinese firms have accomplished the initial capital accumulation during thirty years of economic development, and are capable of investing abroad financially. Our findings are consistent with the strategic asset-seeking motive of OFDI from emerging economies, as OFDI may be utilised by Chinese firms as an approach to acquiring knowledge-related assets overseas to increase their competitiveness and knowledge-based ownership advantages.

The findings show that there is a negative relationship between exports and OFDI, indicating a substitute relationship between Chinese exports and OFDI. Chinese exports started to increase steadily after adopting the 'Open-door' policy and surged dramatically in the new millennium due to low costs (of both materials and labour), large productive capacity and government support. However, China started to face pressure from developed countries because of its large trade surplus, and Chinese firms are under increasing pressure from more and more anti-dumping investigations. Therefore, it is becoming increasingly difficult for Chinese firms to expand their international markets through exports. Meanwhile, increasing labour costs and appreciation of the RMB (the Chinese currency) have also contributed to export difficulties. When exporting is threatened, more and more Chinese firms start conducting OFDI. Our result is consistent with that of existing studies at the industry level (Amighin et al., 2011; Liu et al., 2001) which show that Chinese OFDI in services and manufacturing industries is a substitute for exports. It implies that firms tend to use FDI to replace exports as an alternative mode of internationalisation. 
Compared to human mobility and economic development, IFDI plays a less important role in Chinese OFDI as the variable is partially supported. The results suggest that Chinese OFDI is mainly driven by the country's economic development, two-way human mobility, and substitutes for exports. Furthermore, the control variable, which captures the government support towards Chinese OFDI and the impact of China's WTO entry, had a positive sign in all three models, but was statistically insignificant. This indicates that OFDI, in the long run, is largely driven by ownership advantages accumulated in finance and human capital, as well as strategic incentives to replace exports.

This study contributes to the existing literature in a number of ways. First, it examines the role of an underexplored factor, two-way human mobility, in facilitating OFDI. By incorporating this particular factor into the IDP framework, we are able to provide new empirical evidence on OFDI from emerging economies. The findings help to enhance our understanding of Chinese OFDI at country level and represent an important extension of previous studies by considering the new phenomenon of twoway human mobility between emerging economies such as China and the outside world.

Secondly, the study also complements previous studies at industry and firm level, and provides a broader perspective at the macro-level, which has been taken as given in micro-level analysis. Our findings derived from macro-level analysis call for more firm-level or industry-level studies on how human mobility contributes to the internationalisation of firms from emerging economies when more fine-grained measures are available. 
Thirdly, extending previous studies on the Chinese diaspora, our study adopts a broader concept of human mobility which helps to capture the accelerated pace and new composition of human mobility. Our study also helps to advance the theoretical development of a new driver of internationalisation in the context of emerging economies, and develop international business research by emphasising the importance of human mobility-related advantages in internationalisation, which has been largely ignored in the existing literature.

\section{Implications}

The findings from our study have some important implications for both policy makers and practitioners. First, this study reveals that human mobility can significantly boost OFDI from emerging economies. Compared with developed economies, emerging economies can benefit tremendously from human mobility through knowledge and network spillovers. Our study shows that the 'brain drain' which concerned the Chinese government has turned into brain circulation or 'brain gain' via two-way human mobility. Therefore, instead of concern about the loss of human capital when locals move abroad, the government should focus more carefully on how to take advantage of such mobility since it creates a precious global intelligence network which helps emerging economies, such as China, to accelerate internationalisation and engagement in the global marketplace.

Second, domestic economic development is still the backbone for the global expansion of Chinese firms. Our results imply that as the domestic economy grows, Chinese firms can build their own competitive advantages which can be exploited in the global market. Furthermore, although governmental support may be an incentive 
for OFDI activities, the actual investments are determined by ownership advantages derived from both finance and human capital accumulation. Therefore, the government should promote OFDI activities by devoting its efforts to domestic economic development.

Third, managers should be aware of the importance and availability of internationally mobile talents. The positive effect of human mobility implies that managers should take advantage of such mobility and effectively utilise internationally mobile talents to implement their internationalisation strategy. Such individuals represent bridges and offer networks for local firms that are more inclined to seek new business opportunities beyond their home markets, and may facilitate local firms to invest and operate in foreign markets. This group of people can also bring international experience to local firms which otherwise would have taken a longer time to accumulate. Hence, fully exploiting the value of human mobility may help local firms to develop knowledge-related advantages.

Finally, although our study mainly focused on China, the findings are also relevant to other emerging economies, given that other large economies, such as India, have also experienced significant human mobility and rapid economic growth in recent decades. This implies that human mobility is not country specific but represents a common trend in emerging economies. The governments of other emerging economies may also need to encourage two-way human mobility in order to further boost domestic economic development and accelerate the international expansion of local firms. 


\section{Limitations and Future Studies}

We should acknowledge the limitations of our study. First, our sample period is from 1979 to 2009. Although this represents an improvement on previous studies of Chinese FDI in terms of the sample size (Liu et al., 2005; Wang and Swain, 1995) and also allowed us to perform various pre-tests for time-series analysis, such as unitroot tests and cointegration tests, the relatively short time-series data or limited number of observations may underestimate the predicted power of the main explanatory variables. Specifically, the lack of significance of the knowledge development variable may well reflect this lack of degree of freedom. Future studies should use a longer time span to further verify the relationship between OFDI and the proposed explanatory variables.

Second, due to the complex nature of highly skilled human mobility, detailed statistics data are often unavailable (OECD, 2002). This has posed a great challenge for empirical research on human mobility. Although international student flows account for the majority of the global mobility of highly skilled Chinese people (Zhang and Li, 2002), this does not include people who received all their education in China and later worked abroad as highly skilled migrants. This could result in an underestimate of the impact of highly skilled human mobility on Chinese OFDI. Future studies should examine the composition of human mobility in more detail when data are available in order to increase the likelihood of capturing the impact of such mobility. Furthermore, more detailed studies are needed to investigate the bilateral links between human mobility and OFDI between China and a host country, and to seek further evidence as to whether the growth of global mobility leads to the 
locational choice of Chinese OFDI, or whether there is a connection between the subjects which overseas Chinese students study and OFDI ${ }^{1}$.

Third, while our aggregated approach provides an overall picture of the determinants of Chinese OFDI at the country level, such an approach does not allow us to separate OFDI undertaken by firms with different types of ownership such as state-owned and private enterprises. Previous studies on the determinants of Chinese OFDI are mostly based on activities of Chinese state-owned firms, since Chinese private firms were legally prohibited from investing abroad prior to 2001 (Buckley et al., 2007). Recent studies have found that the state ownership affects entry mode selection (Chen and Young, 2010; Cui and Jiang, 2012). However, the short history of the internationalisation of private firms prevents us from conducting a meaningful econometric analysis. Future studies should utilise disaggregated data to distinguish the similarities and differences between state-owned and private enterprises in their determinants of OFDI activities.

\section{Conclusion}

This paper is one of the first to explore a largely neglected factor, human mobility, in determining a country’s OFDI using time series data from 1979 to 2009. By incorporating the human mobility variable into the original IDP framework along with other determinants, the results reveal that Chinese OFDI has the tendency to

\footnotetext{
${ }^{1}$ We would like to thank an anonymous reviewer for this insightful suggestion.
} 
increase in parallel with its economic development and human mobility, and substitutes for exports. The interdependence and co-movement among the factors have been taken into consideration in our study which thus provides new insights into the determinants of OFDI by considering the impact of two-way human mobility.

\section{Acknowledgement}

The authors are grateful to three anonymous reviewers for their insightful comments. 


\section{Reference}

Adler, P. S. \& Kwon, S. (2002). Social capital: Prospects for a new concept, Academy of Management Review, 27(1), 17-40.

Amighini, A. R., Rabellotti, R. \& Sanfilippo, M. (2011). China's outward FDI: An industry-level analysis of host country determinants, the 22nd CEA (UK) Annual Conference Proceedings.

Backer, K. D. \& Sleuwaegen, L. (2003). Does foreign direct investment crowd out domestic entrepreneurship?, Review of Industrial Organization, 22(1), 67-84.

Barry, F., Görg, H. \& McDowell, A. (2003). Outward FDI and the investment development path of a late-Industrializing economy: Evidence from Ireland, Regional Studies, 37(4), 341-349.

Batjargal, B. (2007). Network triads: transitivity, referral and venture capital decisions in China and Russia, Journal of International Business Studies, 38(6), 998-1012.

Bellak, C. (2001). The Austrian investment development path, Transnational Corporations, 10(2), 107-134.

Blalock G. \& Simon, D. (2009). Do all firms benefit equally from downstream FDI? The moderating effect of local suppliers' capabilities on productivity gains. Journal of International Business Studies, 40(7): 1095-1112. 
Blonigen, B. A. (2005). A review of the empirical literature on FDI determinants, Atlantic Economic Journal, 33(4), 383-403.

Boudier-Bensebaa, F. (2004). FDI-assisted development in the light of the investment development path paradigm: Evidence from Central and Eastern European countries, in the Eighth EACES Conference: Belgrade.

Buckley, P. J. \& Castro, F. B. (1998). The investment development path: The Case of Portugal, Transnational Corporations, 7(1), 1-15.

Buckley, P. J., Clegg, L. J., Cross, A. R., Liu, X., Voss, H. \& Zheng, P. (2007). The determinants of Chinese outward foreign direct investment, Journal of International Business Studies, 38(4), 499-518.

Burke, S. P. \& Hunter, J. (2005). Modelling non-stationary economic time series: A multivariate approach, Palgrave Macmillan: Basingstoke and New York.

Chellaraj, G., Maskus, K. E. \& Mattoo, A. (2005). The contribution of skilled immigration and international graduate students to U.S. innovation, World Bank Working Paper, June, 2005.

Chen, H. \& Chen, T. (1998). Network linkages and location choice in foreign direct investment, Journal of International Business Studies, 29(3), 445-467. 
Chen, Y. Y. \& Young, M. N. (2010). Cross-border merger and acquisitions by Chinese listed companies: A principal-principal perspective, Asia Pacific Journal of Management, 27(3), 523-539.

Cheung, G. C. K. (2004). Chinese diaspora as a virtual name: Interactive roles between economic and social capital, Political Studies, 52, 664-684.

Child, J. (2001). China and international business, in A. M., Rugman \& T. L., Brewer (Eds.). The Oxford Handbook of International Business, 1st edition, Oxford: Oxford University Press.

China Statistical Year Book (1980-2010). China Statistical Year Book: 1980-2010, Beijing: National Bureau of Statistics of China.

Chuang, Y. \& Lin, C. (1999). Foreign direct investment, R\&D and spillover efficiency: Evidence from Taiwan's manufacturing firms, Journal of Development Studies, 35(4), 117-137.

Coviello, N. E. (2006). The network dynamics of international new ventures, Journal of International Business Studies, 37(5), 713-731.

Cui, J. \& Jiang, F. (2012). State ownership effect on firms’ FDI ownership decisions under institutional pressure: A study of Chinese outward-investing firms, Journal of International Business Studies, 43(1), 1-21. 
Docquier, F. \& Marfouk, A. (2004). Measuring the international mobility of skilled workers, 1990-2000, Policy Research Working Paper No 3381, The World Bank, August

Docquier, F. \& Lodigiani, E. (2010). Skilled migration and business networks. Open Economic Review, 21, 565-588.

Docquier, F. \& Rapoport, H. (2011). Globalization, brain drain and development, Journal of Economic Literature, Forthcoming.

Drake, T. A. \& Caves, R. E. (1992). Changing determinants of Japanese foreign investment in the United States, Journal of the Japanese and International Economies, 6(3), 228-246.

Driffield, N. \& Love, J. H. (2007). Linking FDI motivation and host economy productivity effects: Conceptual and empirical analysis, Journal of International Business Studies, 38(3), 460-473.

Dunning, J. H. (1977). Trade, location of economic activity and the MNE: A search for an eclectic approach, in: B. Ohlin, P. O. Hesselborn \& P. M. Wijkman (eds.) The International Allocation for Economic Activity, London: Macmillan.

Dunning, J. H. (1981). Explaining the international direct investment position of countries: Toward a dynamic and development approach, Weltwirtschaftliches Archiv, 117(5), 30-64 
Dunning, J. H. (1986). The investment development cycle revisited, Weltwirtschaftliches Archiv, 122: 667-677

Dunning, J. H. (1993). Multinational enterprises and the global economy, AddisonReading, MA : Wesley Publishing Company.

Dunning, J. H. (2002). Relational assets, networks, and international business activities, in F. J. Contractor \& P. Lorange (Eds.). Cooperative strategies and alliances, Amsterdam: Pergamon, 569-593.

Dunning, J. H. \& Narula, R. (1996). The investment development path revisited: some emerging issues, in J. H. Dunning \& R. Narula (Eds.), Foreign direct investment and governments, London and New York: Routledge, 1-41.

Dunning, J. H, Kim, C. \& Lin, J. (2001). Incorporating trade into the investment development path: A case study of Korea and Taiwan, Oxford Development Studies, 29(2), 145-154

Erdener, C. \& Shapiro, D. M. (2005). The internationalisation of Chinese family enterprises and Dunning's eclectic MNE paradigm, Management and Organization Review, 1(3), 411-436.

Filatotchev, I., Liu, X., Buck, T. \& Wright, M. (2009). The export orientation and export performance of high-technology SMEs in emerging markets: The effects of knowledge transfer by returnee entrepreneurs, Journal of International Business Studies, 40(6), 1005-1021. 
Filatotchev, I., Liu, X., Lu, J. \& Wright, M. (2011). Knowledge spillovers through human mobility across national borders: Evidence from Zhongguancun Science Park in China, Research Policy, 40(3), 453 - 462.

Furman, J., Porter, M. \& Stern, S. (2002). The determinants of national innovative capacity, Research Policy, 31(6), 899-933.

Gassmann, O. \& Keupp, M. M. (2007). The competitive advantage of early and rapidly internationalizing SMEs in the biotechnology industry: A knowledge-based view. Journal of World Business, 42 (3), 350-366.

GCIM (2005). Migration in an interconnected world: New directions for action. Report of the Global Commission on International Migration. Retrieved on 25 October 2011, from http://www.gcim.org/attachements/gcim-complete-report-2005.pdf

Gulati, R., Nohria, N. \& Zaheer, A. (2000) Strategic networks, Strategic Management Journal, 21(3, Special Issue: Strategic Networks), 203-215.

Guo, Z., Chen, J., Xie, P., Zhang, D. \& Lin, A. (2009). 2008 World Chinese entrepreneurs development report, Beijing: China News Service.

Hanaki, N., Peterhansl, A., Dodds, P. S., \& Watts, D. J. (2007) Cooperation in evolving social networks, Management Science, 53(7), 1036-1050.

Head, K. \& Ries, J. (2001). Overseas investment and firm exports, Review of International Economics, 9(1), 108-122. 
Holburn, G. L. F., \& Zelner, B. A. (2010). Policy risk, political capabilities and international investment strategy: Evidence from the global electric power industry, Strategic Management Journal, 31(2), 1290-1315.

International Organization for Migration (2010) World migration report 2010: The future of migration, Switzerland: International Organization for Migration.

Jean, R., Tan, D. \& Sinkovics, R. (2011). Ethnic ties, location choice, and firm performance in foreign direct investment: A study of Taiwanese business groups FDI in China, International Business Review, 20(6): 627-635.

Jones, M. V., Coviello, N. \& Tang, Y. K. (2011) International entrepreneurship research (1989-2009): A domain ontology and thematic analysis, Journal of Business Venturing, 26, 632-659.

Kaplan, S. (2008). Framing contests: strategy making under uncertainty, Organization Science, 19(5), 729-752.

Kugler, M. \& Rapoport, H. (2005). Skilled emigration, business networks and foreign direct investment, CESIFO working paper NO. 1455.

Kugler, M. \& Rapoport, H. (2007), International labour and capital flows: Substitutes or complements? Economics Letters, 92(2): 155-162.

Lau, H. F. (2003). Industry evolution and internationalisation processes of firms from a newly industrialized economy, Journal of Business Research, 56(10), 847-852. 
Le, T. (2010). Are student flows a significant channel of R\&D spillovers from the North to the South?, Economic Letter, 107: 315-317.

Li, X. (2011). Sources of external technology, absorptive capacity, and innovation xapability in Chinese state-owned high-tech enterprises. World Development, 39(7), 1240-1248.

Liu, X., Buck, T. \& Shu, C. (2005). Chinese economic development, the next stage: Outward FDI?, International Business Review, 14(1), 97-115.

Liu, X., Wang, C. and Wei, Y. (2001). Causal links between foreign direct investment and trade in China, China Economic Review, 12, 190-202.

Lu, J., Liu, X., \& Wang, H. (2011). Motives for Chinese outward FDI: Firm resources, industry dynamics, and government policies, Management and Organisation Review, 7(2), 223-248.

Luo, Y. \& Tung, R. L. (2007). International expansion of emerging market enterprises: A springboard perspective, Journal of International Business Studies, 38(4), 481498.

Luo, Y., Xue, Q., \& Han, B. (2010) How emerging market governments promote outward FDI: Experience from China, Journal of World Business, 45(1): 68-79.

Maddala, G. S. \& Lahiri, K., (2009), Introduction to econometrics, England: John Wiley \& Sons Ltd. 
Madhavan, R. \& Iriyama, A. (2009). Understanding global flows of venture capital: Human networks as the carrier wave of globalisation, Journal of International Business Studies, 40(8), 1241-1259.

Makino, S., Lau, C. M., \& Yeh, R. S. (2002). Asset-exploitation Vs asset-seeking: implications for location choice of foreign direct investment from newly industrialized economies. Journal of International Business Studies, 33(3): 403421.

March, J. G. (1991). Exploration and exploitation in organizational learning. Organization Science, 2(1): 71-87.

Mathews, J. A. (2006). Dragon multinationals: New players in 21st Century globalization. Asia Pacific Journal of Management, 23(1), 5-27.

Meyer, K. E., Wright, M. \& Pruthi, S. (2009). Managing knowledge in foreign entry strategy: A resource-based analysis, Strategic Management Journal, 30(5), 557574.

Ministry of Education (2011). Retrieved on 9/10/2011 , from http://www.moe.edu.cn/ publicfiles/business/htmlfiles/moe/moe_851/201006/90108.html

MOC (2011). 2010 Statistical Bulletin of China's Outward Foreign Direct Investment, MOC: Beijing 
Morck, R., Yeung, B., \& Zhao, M. (2008). Perspectives on China's outward foreign direct investment. Journal of International Business Studies, 39(3), 337-350.

Nair, A. \& Filer, L. (2003). Cointegration of firm strategies within groups: A long-run analysis of firm behaviour in the Japanese steel industry. Strategic Management Journal, 24: 145-159.

Neter, J., Wasserman, W., \& Kutner, M. (1996). Applied linear statistical models. Irwin: McGraw-Hill.

Ng, L. F. Y. \& Tuan, C. (2002). Building a favourable investment environment: Evidence for the facilitation of FDI in China, The World Economy, 25(8), 1095-1114

OECD (2002). International mobility of the highly skilled, France: OECD Publication Service.

Park, J. (2004). International student flows and R\&D spillovers, Economics Letters, 82: 315-520.

Peng, M. W. (2001). Business strategies in transition economies, Academy of Management Review, 26(2), 311-313.

Porter, M. E. (1990). The competitive advantage of nations. New York: Free Press.

Rob, R. \& Vettas, N. (2003). Foreign direct investment and exports with growing demand, Review of Economic Studies, 70(3), 629-648. 
Saxenian, A. (2002). Transnational communities and the evolution of global production networks: The cases of Taiwan, China and India, Industry and Innovation, 9(3), 183-202.

Saxenian, A. (2006). The new Argonauts: Regional advantage in a global economy, Massachusetts: Harvard University Express.

Scott-Kennel, J. \& Enderwick, P. (2005). FDI and inter-firm linkages: Exploring the black box of the investment development path, Transnational Corporations, 14(1), 105-139.

Sharma, D. D. \& Blomstermo, A. (2003). The internationalisation process of born globals: A network view, International Business Review, 12(6), 739-753.

Singh, N. \& Kundu, S. (2002). Explaining the growth of e-commerce corporations (ECCs): An extension and application of the eclectic paradigm, Journal of International Business Studies, 33(4), 679-697.

Smart, A. \& Hsu, J. (2004). The Chinese diaspora, foreign investment and economic development in China, The Review of International Affairs, 3(4), 544-566.

Spence, M., \& Crick, D. (2009). An exploratory study of Canadian international new venture firms' development in overseas markets. Qualitative Market Research: An International Journal, 12 (2), 208-233. 
Swenson, D. L. (2004). Foreign investment and the mediation of trade flows, Review of International Economics, 12(4), 609-629.

Toda, H. \& Phillips, C. (1993) Vector autoregression and causality, Econometrica, 61, 1367-1393.

Tung, R. L. (2008). Brain circulation, diaspora, and international competitiveness, European Management Journal, 26(5), 298-304.

Tung, R. L. \& Chung, H. F. L. (2010). Diaspora and trade facilitation: The case of ethnic Chinese in Australia, Asia Pacific Journal of Management, 27(3), 371-392.

Wang, H. (2007). Contemporary Chinese returnees, Beijing: China Development Publishing House.

Wang, Z. Q. \& Swan, N. J. (1995). The determinants of foreign direct investment in transforming economies: Empirical evidence from Hungary and China , Weltwirtchaftliches Archiv, 131, 359-82.

Wei, Y., Liu, X. \& Wang, C. (2008). Mutual productivity spillovers between foreign and local Firms in China, Cambridge Journal of Economics, 32, 609-631.

WIR (2010). World investment report 2010: Investing in a low-carbon economy, New York: United Nation. 
Witt, M. A., \& Lewin, A. Y. (2007). Outward foreign direct investment as escape response to home country institutional constraints. Journal of International Business Studies, 38(4): 579-594.

World Bank (2011). World Bank indicator, from http://data.worldbank.org/indicator

UNCTAD (2011). UNCTAD FDI Database, from http://www.unctad.org

UNESCO (2010). Global education digest 2010, Canada: UNESCO Institute for Statistics.

Zahra, S.A. \&Hayton, J.C. (2008). The effect of international venturing on firm performance: the moderating influence of absorptive capacity. Journal of Business Venturing, 23 (2), 195-220.

Zhan, J. X. (1995). Transnationalisation and outward investment: The case of Chinese firms, Transnational Corporations, 4(3), 67-100.

Zhang, H. \& Bulcke, D. (1996). China: Rapid changes in the investment development path, in: J. H. Dunning \& R. Narula (Eds.). Foreign direct investment and government: Catalysts for economic restructuring (pp. 380-422), London: Routledge.

Zhang, G. \& Li, W. (2002). International mobility of China’s resources in science and technology and its impact, in OECD (Eds.) International mobility of the highly skilled, France: OECD Publication Service. 
Zhou, L., Wu, W. \& Luo, X. (2007). Internationalisation and the performance of bornglobal SMEs: The mediating role of social networks, Journal of International Business Studies, 38(4), 673-690.

Zwinkels, R. C. J., \& Beugelsdijk, S. (2010). Gravity equations: workhorse or Trojan Horse in explaining trade and FDI patterns across time and space?, International Business Review, 19(1), 102-115. 
Table 1 Augmented Dickey-Fuller Tests for Unit Roots

\begin{tabular}{lll}
\hline Variables & ADF at level & ADF at first difference \\
\hline LogOFDI & -0.588 & $-3.230^{*}$ \\
LogGDPP & 0.558 & $-2.825^{*}$ \\
LogHMIS & 1.075 & $-13.582^{* * *}$ \\
LogHMNS & -2.571 & $-3.650^{* *}$ \\
LogFDI & -0.671 & $-3.575^{* *}$ \\
LogEXPORT & -1.999 & $-1.627^{*}$ \\
LogR\&D & -2.046 & $-3.351^{*}$ \\
\hline
\end{tabular}

Note: (1) ***, ** and * denote significance at the 1, 5 and 10\% levels, respectively. (2) The lag length was chosen using residual tests on serial correlations.

Table 2 Cointegration Tests

\begin{tabular}{|c|c|c|c|c|c|c|}
\hline \multirow{2}{*}{$\begin{array}{l}\text { No. of } \\
\text { CE(s) }\end{array}$} & \multicolumn{2}{|c|}{ Model 1} & \multicolumn{2}{|c|}{ Model 2} & \multicolumn{2}{|c|}{ Model 3} \\
\hline & Trace & $\lambda_{\max }$ & Trace & $\lambda_{\max }$ & Trace & $\lambda_{\max }$ \\
\hline None & $174.68 * * *$ & $109.10^{* * *}$ & $112.64^{* *}$ & $47.41^{* *}$ & $182.95 * * *$ & $82.06 * * *$ \\
\hline At most 1 & 65.57 & 30.81 & 65.23 & 27.73 & 100.88 & 35.98 \\
\hline At most 2 & 34.76 & 17.99 & 37.49 & 17.07 & 64.91 & 26.45 \\
\hline At most 3 & 16.77 & 9.22 & 20.42 & 12.02 & 38.45 & 17.34 \\
\hline At most 4 & 7.54 & 7.39 & 8.40 & 5.57 & 21.12 & 12.29 \\
\hline At most 5 & 0.16 & 109.10 & 2.83 & 2.83 & 8.83 & 6.42 \\
\hline
\end{tabular}

Note: *** and $* *$ denotes significance at the $1 \%$ and $5 \%$ levels, respectively. 


\section{Table 3 System Exogeneity Tests (LR-test):}

\begin{tabular}{llll}
\hline \multicolumn{1}{c}{ Variables } & Model 1 & Model 2 & Model 3 \\
\hline LogGDPP weakly exogenous to system & 0.13 & 0.64 & 0.04 \\
LogHMIS weakly exogenous to system & $63.11^{* * *}$ & & $62.41^{* * *}$ \\
LogHMNS weakly exogenous to system & & 2.79 & 0.79 \\
LogFDI weakly exogenous to system & 1.34 & 0.38 & 0.01 \\
LogEXPORT weakly exogenous to system & 3.55 & 2.62 & 1.17 \\
LogR\&D weakly exogenous to system & 2.89 & $3.72^{* *}$ & $5.84^{* *}$ \\
\hline
\end{tabular}

Note: *** and $* *$ denotes significance at the $1 \%$ and $5 \%$ levels, respectively.

Table 4 Descriptive Statistics and Correlation Matrix

\begin{tabular}{lllllllllll}
\hline & Variables & Mean & s.d. & 1 & 2 & 3 & 4 & 5 & 6 & 7 \\
\hline 1 & $\Delta$ LogOFDI & 0.24 & 0.29 & 1.00 & & & & & & \\
2 & $\Delta$ LogGDPP & 0.08 & 0.03 & 0.34 & 1.00 & & & & & \\
3 & $\Delta$ LogHMIS & 0.25 & 0.26 & 0.31 & -0.04 & 1.00 & & & & \\
4 & $\Delta$ LogHMNS & 0.21 & 0.16 & 0.62 & 0.02 & 0.45 & 1.00 & & & \\
5 & $\Delta$ LogFDI & 0.15 & 0.13 & 0.64 & 0.20 & 0.23 & -0.29 & 1.00 & & \\
6 & $\Delta$ LogEXPORT & 0.11 & 0.10 & -0.48 & 0.30 & -0.17 & 0.19 & -0.58 & 1.00 & \\
7 & $\Delta$ LogR\&D & 0.10 & 0.12 & -0.07 & 0.25 & -0.22 & -0.19 & -0.15 & 0.26 & 1.00 \\
\hline
\end{tabular}

Note: s.d.=Standard Deviation.

Table 5 VIF Test

\begin{tabular}{llll}
\hline Variables & Model 1 & Model 2 & Model 3 \\
\hline$\Delta$ LogGDPP & 1.47 & 1.48 & 1.97
\end{tabular}




\begin{tabular}{lccc}
\hline$\Delta$ LogHMIS & 1.30 & & 1.84 \\
$\Delta$ LogHMNS & & 1.09 & 1.34 \\
$\Delta$ LogFDI & 2.29 & 2.05 & 2.24 \\
$\Delta$ LogEXPORT & 2.16 & 2.41 & 2.69 \\
$\Delta$ LogR\&D & 1.12 & 1.16 & 1.33 \\
\hline Average VIF & 1.67 & 1.64 & 1.90 \\
\hline
\end{tabular}

Table 6 The Determinants of Chinese OFDI

\begin{tabular}{|c|c|c|c|c|c|}
\hline Independent variables & $\begin{array}{l}\text { Model } 1 \\
\text { (OLS) }\end{array}$ & $\begin{array}{l}\text { Model } 2 \\
\text { (OLS) }\end{array}$ & $\begin{array}{l}\text { Model } 3 \\
\text { (GMM) }\end{array}$ & $\begin{array}{l}\text { Model } 4 \\
\text { (GMM) }\end{array}$ & $\begin{array}{l}\text { Model } 5 \\
\text { (GMM) }\end{array}$ \\
\hline \multirow{2}{*}{$\triangle \mathrm{LogGDPP}$} & $3.68^{*}$ & $4.38^{* *}$ & $4.78^{* *}$ & $3.29 * * *$ & $2.37 * *$ \\
\hline & $(1.93)$ & $(1.81)$ & (1.79) & $(1.18)$ & $(0.96)$ \\
\hline \multirow{2}{*}{$\Delta \operatorname{LogHMIS}(-1)$} & & & $0.81^{* * *}$ & & $0.84 *$ \\
\hline & & & $(0.15)$ & & $(0.42)$ \\
\hline \multirow{2}{*}{$\Delta \operatorname{LogHMNS}(-5)$} & & & & $0.91 * * *$ & $0.70 * * *$ \\
\hline & & & & $(0.12)$ & $(0.13)$ \\
\hline \multirow{2}{*}{$\Delta \mathrm{LogFDI}$} & & 0.72 & $0.66 *$ & 0.31 & 0.48 \\
\hline & & $(0.44)$ & $(0.38)$ & $(0.35)$ & $(0.27)$ \\
\hline \multirow{2}{*}{$\Delta$ LogEXPORT } & & $-1.14^{* *}$ & $-0.97^{* *}$ & $-0.79 * *$ & $-0.67 * *$ \\
\hline & & $(0.54)$ & $(0.36)$ & $(0.35)$ & $(0.26)$ \\
\hline \multirow{2}{*}{$\Delta \operatorname{LogR} \& \mathrm{D}$} & & -0.04 & -0.85 & -0.13 & -0.23 \\
\hline & & $(0.35)$ & $(0.28)$ & $(0.32)$ & $(0.17)$ \\
\hline \multirow{2}{*}{ GoAbroad } & & & 0.04 & 0.05 & 0.04 \\
\hline & & & $(0.05)$ & $(0.03)$ & $(0.04)$ \\
\hline \multirow{2}{*}{ ЕСТ(-1) } & & & -0.04 & $-0.71^{* *}$ & $-0.63^{* *}$ \\
\hline & & & $(0.20)$ & $(0.31)$ & $(0.24)$ \\
\hline \multirow{2}{*}{$\mathrm{C}$} & -0.07 & -0.11 & $-0.27 * * *$ & $-0.28 * * *$ & $-0.28 * * *$ \\
\hline & $(0.70)$ & $(0.13)$ & $(0.05)$ & $(0.09)$ & $(0.07)$ \\
\hline
\end{tabular}




\begin{tabular}{llllll}
\hline Adjusted $\mathrm{R}^{2}$ & 0.08 & 0.46 & 0.62 & 0.67 & 0.78 \\
\hline No. of Observation & 30 & 30 & 27 & 25 & 25 \\
\hline
\end{tabular}

Note: (1) ***, ** and * denote significance at the $1 \%, 5 \%$ and $10 \%$ levels, respectively. (2) Standard error in brackets. (3) ECT represents the long-run equilibrium relationship between the variables and is fed into the short-run relationship. (4) The number of observations of models 3-5 is reduced because of regressing on first difference and using lagged variables. 